Check for updates

Cite this: RSC Adv., 2017, 7, 29071

Received 15th April 2017

Accepted 29th May 2017

DOI: $10.1039 / c 7 r a 04267 a$

rsc.li/rsc-advances

\title{
Highly oxygenated caryophyllene-type and drimane-type sesquiterpenes from Pestalotiopsis adusta, an endophytic fungus of Sinopodophyllum hexandrum $\dagger$
}

\author{
Jian Xiao, D † $^{\star a}$ Libin Lin,,$^{\mathrm{a}}$ Jiayao Hu, ${ }^{a}$ Furong Jiao, ${ }^{a}$ Dongzhu Duan, ${ }^{a}$ Qiang Zhang, ${ }^{\mathrm{b}}$ \\ Haoyu Tang, (D) Jinming Gao, (D) ${ }^{b}$ Le Wang $^{\mathrm{a}}$ and Xiaoling Wang (D) *a
}

\begin{abstract}
Four new highly oxidized caryophyllene-type sesquiterpenes (1-4), one new caryophyllene-type natural product (5), and two new drimane-type sesquiterpenes $(6,7)$, along with eight known compounds have been isolated from an endophytic fungus Pestalotiopsis adusta. Their structures were elucidated on the basis of HRESIMS, 1D and 2D NMR spectroscopic data analyses. The absolute configurations for 1 and 5 were determined by single-crystal $\mathrm{X}$-ray crystallographic analysis using $\mathrm{Cu} \mathrm{K} \alpha$ radiation. The absolute configuration of 6 was determined by CD spectrum associated with TD-DFT calculation of its benzoylated derivative $6 \mathrm{a}$. The in vitro bioassay revealed that 8 and 9 presented cytotoxicity against cancer cell lines A549, HeLa, and SMMC-7721, in which 8 showed comparable activity $\left(\mathrm{IC}_{50}=28.3 \mu \mathrm{M}\right)$ to the positive control etoposide $\left(\mathrm{IC}_{50}=23.2 \mu \mathrm{M}\right)$ against SMMC-7721
\end{abstract}

\section{Introduction}

Plant endophytic fungi are well known for their potential to produce abundant secondary metabolites and contribute greatly to the discovery of new medicines. ${ }^{\mathbf{1 , 2}}$ The fungal genus of Pestalotiopsis is one of the most commonly found endophytes on the planet, 234 species of which are listed in Index Fungorum. ${ }^{3}$ Since a broad-spectrum antitumor drug taxol identified from P. microspora, a plant endophyte of Taxus wallachiana, exploring for the bioactive secondary metabolites from endophytes of the Pestalotiopsis genus of different plants has attracted much attention. ${ }^{4}$ Species of Pestalotiopsis are proved to be a rich source for natural products, and the chemical investigations of Pestalotiopsis spp. have afforded over 300 bioactive secondary metabolites ${ }^{5,6}$ including terpenoids, alkaloids, quinonoids, phenylpropanoids and lactones with diverse

\footnotetext{
${ }^{a}$ Shaanxi Key Laboratory of Phytochemistry, College of Chemistry and Chemical Engineering, Baoji University of Arts and Sciences, Baoji 721013, Shaanxi, P. R. China.E-mail: xjxs163@126.com; xlwangwang@163.com; Tel: +86-917-3566233 ${ }^{b}$ Shaanxi Key Laboratory of Natural Products \& Chemical Biology, College of Chemistry \& Pharmacy, Northwest A\&F University, Yangling 712100, Shaanxi, P. R. China

${ }^{c}$ State Key Laboratory of Bioorganic and Natural Products Chemistry, Shanghai Institute of Organic Chemistry, Chinese Academy of Sciences, Shanghai 200032, P. R. China

$\dagger$ Electronic supplementary information (ESI) available. CCDC 1534582 and 1534584. For ESI and crystallographic data in CIF or other electronic format see DOI: $10.1039 / \mathrm{c} 7 \mathrm{ra04267a}$

\$ These authors contributed equally to this work.
}

bioactivities such as antitumor, antibacterial, acetylcholinesterase inhibitory, antioxidant and anti-HIV. ${ }^{7-10}$

$\beta$-Caryophyllene, a sesquiterpene characteristic of a strained four-membered ring and a flexible nine-membered macrocyclic moiety, exists popularly in the essential oils from medicinal plants. It acts as a key precursor in nature to form tricyclic and tetracyclic highly oxygenated caryophyllene-type sesquiterpenes by transannular rearrangements. ${ }^{11}$ Its highly oxygenated derivatives were proved to possess significant bioactivities, including immunosuppressive activity, ${ }^{7}$ affecting growth and proliferation of numerous cancer cells, ${ }^{12}$ antibacterial activity, ${ }^{13}$ and anti-inflammatory activity. ${ }^{14}$ Although $\beta$-caryophyllene is widely distributed, its highly oxygenated derivatives are not common. ${ }^{7}$ Until now, only a few highly oxygenated caryophyllene-type sesquiterpenes have been reported from terrestrial plant endophyte, including three unprecedented novel compounds cytosporinols A-C. ${ }^{15-24}$ The highly oxygenated caryophyllenetype sesquiterpenes also attracted the interests of synthetic chemists due to their structural characteristics and special bioactivities. ${ }^{25}$

In our continuous screening for bioactive natural products from plant endophytes, ${ }^{26-28}$ we investigated an endophytic fungus Pestalotiopsis adusta collected from the stem bark of wild rare medicinal plant Sinopodophyllum hexandrum (Royle) Ying in Qinling Mountains. The chemical investigation on the solid culture of $P$. adusta led to the isolation of four new highly oxidized caryophyllene-type sesquiterpenes pestalotiopsins D-G (1-4), two new drimane-type sesquiterpenes pestalotiophol $\mathrm{A}$ and $\mathrm{B}(6,7)$, along with nine known compounds 

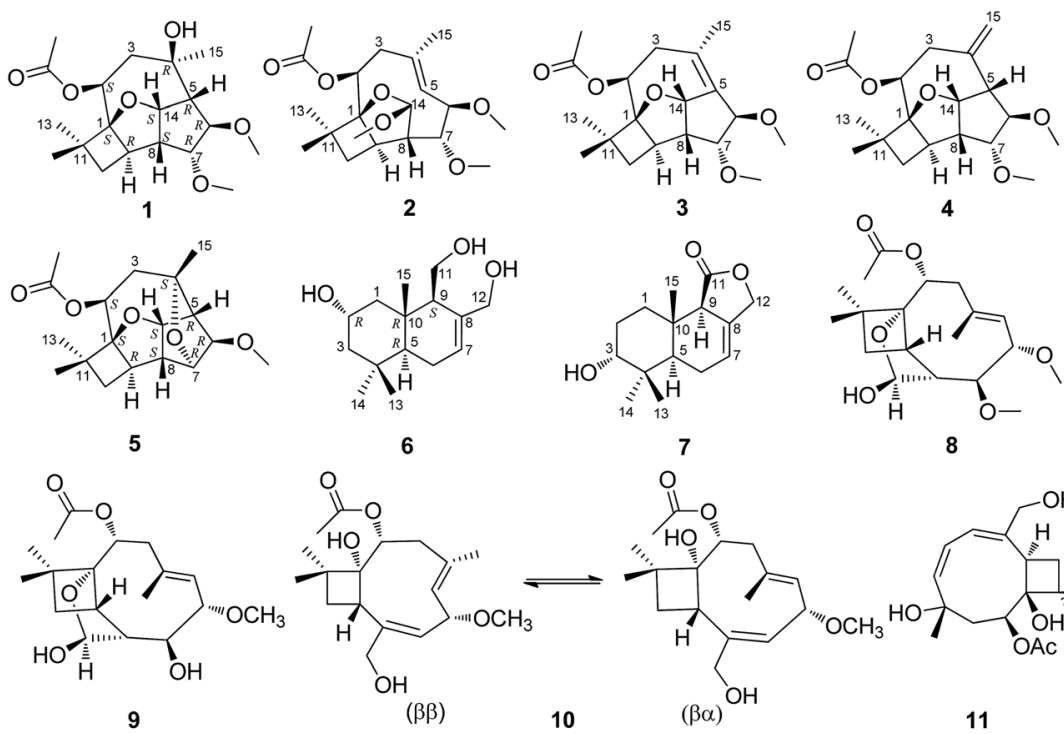

6

7

8

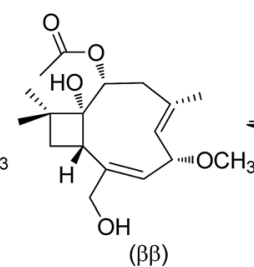

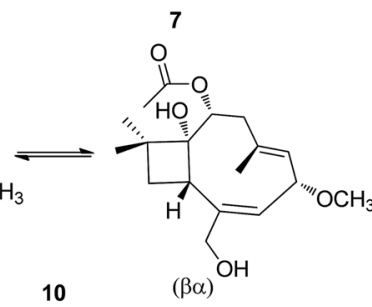<smiles>CC(C)C1C(O)=CC=CC(C)C(C)C1O</smiles>

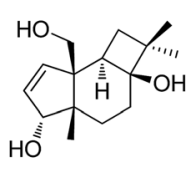

12
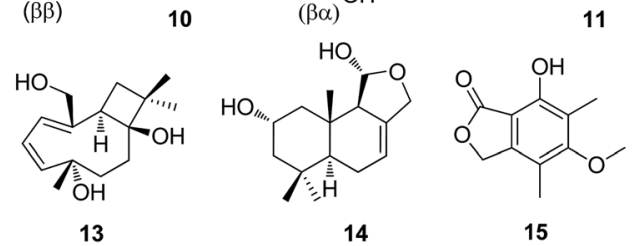

Fig. 1 Structures of compounds 1-15.

pestalotiopsin $\mathrm{H}(5),{ }^{25}$ pestalotiopsin C $(8),{ }^{29}$ pestalotiopsin A (9), ${ }^{29}$ pestalotiopsin B $(\mathbf{1 0}),{ }^{29}$ punctaporonin $\mathrm{H}(\mathbf{1 1}),{ }^{30}$ punctatin A (12), ${ }^{31}$ punctaporonin B (13), ${ }^{30} 2 \alpha$-hydroxydimeninol (14), ${ }^{32}$ and 7-hydroxy-5-methoxy-4,6-dimethylphthalide (15), ${ }^{33}$ of which 5 was a new natural product (Fig. 1). Details of the isolation, structure elucidation, and cytotoxicity of these secondary metabolites are reported herein.

\section{Results and discussions}

Pestalotiopsin D (1) was obtained as a white amorphous powder, its molecular formula was deduced to be $\mathrm{C}_{19} \mathrm{H}_{30} \mathrm{O}_{6}$ with five degrees of unsaturation based on HRESIMS at $m / z 377.1931$ $\left([\mathrm{M}+\mathrm{Na}]^{+}\right.$, calcd for 377.1940). The ${ }^{1} \mathrm{H}$ NMR (Table 1) spectrum revealed that 1 had two methoxyls $\left[\delta_{\mathrm{H}} 3.36\left(3 \mathrm{H}, \mathrm{s}, \mathrm{OCH}_{3}-6\right), 3.27\right.$ $\left.\left(3 \mathrm{H}, \mathrm{s}, \mathrm{OCH}_{3}-7\right)\right]$, four tertiary methyls $\left[\delta_{\mathrm{H}} 1.06\left(3 \mathrm{H}, \mathrm{s}, \mathrm{H}_{3}-12\right)\right.$,

Table $1{ }^{1} \mathrm{H}$ NMR data for compounds $1-5$ at $400 \mathrm{MHz}$ in $\mathrm{CDCl}_{3}(\delta$ in ppm, $\mathrm{J}$ in $\mathrm{Hz}$ )

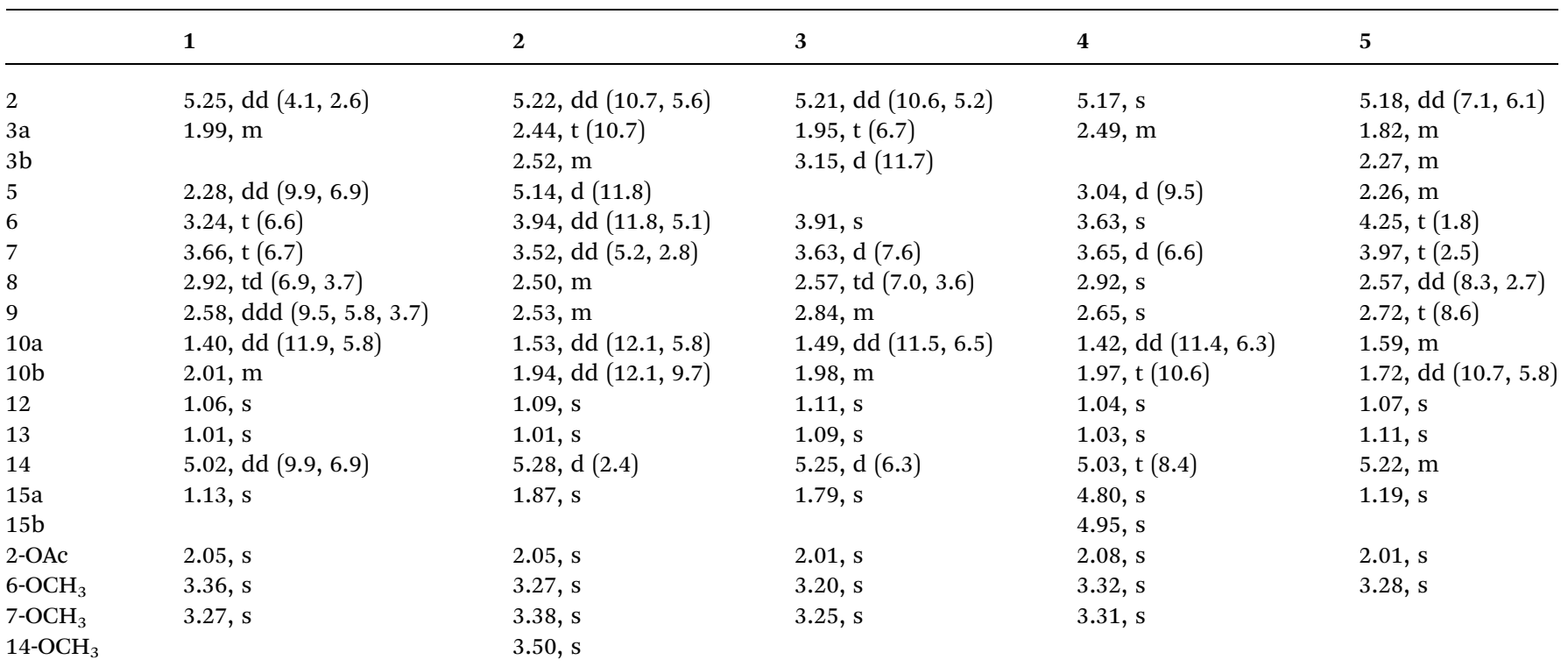


Table $2{ }^{13} \mathrm{C}$ NMR data for compounds $1-5$ at $100 \mathrm{MHz}$ in $\mathrm{CDCl}_{3}(\delta$ in ppm)

\begin{tabular}{|c|c|c|c|c|c|}
\hline Position & 1 & 2 & 3 & 4 & 5 \\
\hline 1 & $94.0, \mathrm{C}$ & $98.0, \mathrm{C}$ & $92.2, \mathrm{C}$ & 94.0, C & 94.6, C \\
\hline 2 & $74.0, \mathrm{CH}$ & 73.7, $\mathrm{CH}$ & $78.5, \mathrm{CH}$ & 72.1, $\mathrm{CH}$ & 75.9, $\mathrm{CH}$ \\
\hline 3 & $37.9, \mathrm{CH}_{2}$ & $41.2, \mathrm{CH}_{2}$ & $34.4, \mathrm{CH}_{2}$ & $34.5, \mathrm{CH}_{2}$ & $41.4, \mathrm{CH}_{2}$ \\
\hline 4 & 74.6, C & $136.3, \mathrm{C}$ & 129.7, C & $142.5, \mathrm{C}$ & 79.8, C \\
\hline 5 & $56.8, \mathrm{CH}$ & $125.4, \mathrm{CH}$ & $133.8, \mathrm{C}$ & $56.9, \mathrm{CH}$ & $51.7, \mathrm{CH}$ \\
\hline 6 & $87.4, \mathrm{CH}$ & $82.0, \mathrm{CH}$ & 81.9, CH & $89.2, \mathrm{CH}$ & $87.9, \mathrm{CH}$ \\
\hline 7 & $85.9, \mathrm{CH}$ & $87.5, \mathrm{CH}$ & $83.5, \mathrm{CH}$ & $85.4, \mathrm{CH}$ & $77.0, \mathrm{CH}$ \\
\hline 8 & $56.2, \mathrm{CH}$ & $61.1, \mathrm{CH}$ & $54.2, \mathrm{CH}$ & $56.1, \mathrm{CH}$ & 49.9, CH \\
\hline 9 & $34.3, \mathrm{CH}$ & $38.3, \mathrm{CH}$ & $39.5, \mathrm{CH}$ & $34.4, \mathrm{CH}$ & 38.6, CH \\
\hline 10 & $40.2, \mathrm{CH}_{2}$ & $42.5, \mathrm{CH}_{2}$ & $42.1, \mathrm{CH}_{2}$ & $40.3, \mathrm{CH}_{2}$ & $37.5, \mathrm{CH}_{2}$ \\
\hline 11 & $37.5, \mathrm{C}$ & $39.8, \mathrm{C}$ & $38.1, \mathrm{C}$ & $37.1, \mathrm{C}$ & 38.6, C \\
\hline 12 & 24.5, $\mathrm{CH}_{3}$ & $24.1, \mathrm{CH}_{3}$ & $23.9, \mathrm{CH}_{3}$ & $24.1, \mathrm{CH}_{3}$ & 23.1, $\mathrm{CH}_{3}$ \\
\hline 13 & 26.1, $\mathrm{CH}_{3}$ & $27.4, \mathrm{CH}_{3}$ & $26.8, \mathrm{CH}_{3}$ & $26.2, \mathrm{CH}_{3}$ & $25.1, \mathrm{CH}_{3}$ \\
\hline 14 & $84.5, \mathrm{CH}$ & 115.1, CH & $89.0, \mathrm{CH}$ & $85.5, \mathrm{CH}$ & $88.8, \mathrm{CH}$ \\
\hline 15 & 29.4, $\mathrm{CH}_{3}$ & $17.5, \mathrm{CH}_{3}$ & $22.1, \mathrm{CH}_{3}$ & $118.3, \mathrm{CH}_{2}$ & $31.6, \mathrm{CH}_{3}$ \\
\hline \multirow[t]{2}{*}{ 2-OAc } & $170.4, \mathrm{C}$ & $170.6, \mathrm{C}$ & $170.3, \mathrm{C}$ & $170.7, \mathrm{C}$ & $170.4, \mathrm{C}$ \\
\hline & 21.6, $\mathrm{CH}_{3}$ & 21.7, $\mathrm{CH}_{3}$ & 21.7, $\mathrm{CH}_{3}$ & 21.5, $\mathrm{CH}_{3}$ & $21.5, \mathrm{CH}_{3}$ \\
\hline $6-\mathrm{OCH}_{3}$ & $57.7, \mathrm{CH}_{3}$ & $56.1, \mathrm{CH}_{3}$ & $55.3, \mathrm{CH}_{3}$ & $57.5, \mathrm{CH}_{3}$ & $57.5, \mathrm{CH}_{3}$ \\
\hline 7- $-\mathrm{OCH}_{3}$ & $57.4, \mathrm{CH}_{3}$ & $57.7, \mathrm{CH}_{3}$ & $57.2, \mathrm{CH}_{3}$ & $57.8, \mathrm{CH}_{3}$ & \\
\hline $14-\mathrm{OCH}_{3}$ & & $56.3, \mathrm{CH}_{3}$ & & & \\
\hline
\end{tabular}

$\left.1.01\left(3 \mathrm{H}, \mathrm{s}, \mathrm{H}_{3}-13\right), 1.13\left(3 \mathrm{H}, \mathrm{s}, \mathrm{H}_{3}-15\right), 2.05(3 \mathrm{H}, \mathrm{s}, \mathrm{OAc})\right]$, and four oxygenated methines $\left[\delta_{\mathrm{H}} 5.25,(1 \mathrm{H}, \mathrm{dd}, J=4.1 / 2.6 \mathrm{~Hz}, \mathrm{H}-2)\right.$, $3.24(1 \mathrm{H}, \mathrm{t}, J=6.6 \mathrm{~Hz}, \mathrm{H}-6), 3.66(1 \mathrm{H}, \mathrm{t}, J=6.7 \mathrm{~Hz}, \mathrm{H}-7), 5.02$ $(1 \mathrm{H}, \mathrm{dd}, J=9.9 / 6.9 \mathrm{~Hz}, \mathrm{H}-14)]$. The ${ }^{13} \mathrm{C}$ NMR spectrum (Table 2), together with DEPT135 and HSQC, revealed the existence of nineteen carbon atoms including one acetoxyl (for its methyl and carbonyl), two methoxyls, three tertiary methyls, two methylenes, seven methines (four oxygenated) and three quaternary carbons. The proton resonances were well assigned to relevant carbon atoms by HSQC. The NMR signals of protons and carbons were characteristic for caryophyllene-type sesquiterpene. ${ }^{29}$ One acetoxy group that accounted for one of the five indices of unsaturation implied that $\mathbf{1}$ had a tetracyclic ring system. The ${ }^{1} \mathrm{H}^{-1} \mathrm{H}$ COSY correlations established two isolated systems (Fig. 2). ${ }^{1} \mathrm{H}-{ }^{1} \mathrm{H}$ COSY correlations of $\mathrm{H}-14$ with $\mathrm{H}-5, \mathrm{H}-5$ with $\mathrm{H}-6, \mathrm{H}-6$ with $\mathrm{H}-7, \mathrm{H}-7$ with $\mathrm{H}-8$ and $\mathrm{H}-8$ with $\mathrm{H}-14$ constructed a five-membered carbon ring of C-5/C-6/C-7/C-8/C-14. ${ }^{1} \mathrm{H}_{-}{ }^{1} \mathrm{H}$ COSY correlations of $\mathrm{H}-14$ with $\mathrm{H}-8$ and $\mathrm{H}-8$ with $\mathrm{H}-9$, HMBC correlations of $\mathrm{H}-8$ with C-9/C-1 and $\mathrm{H}-14$ with $\mathrm{C}-1$, and consideration of the downfield chemical shifts of $\mathrm{C}-1$ and C-14, constructed a five membered tetrahydrofuran ring of C-8/ $\mathrm{C}-9 / \mathrm{C}-1 / \mathrm{O} / \mathrm{C}-14 .{ }^{1} \mathrm{H}^{-1} \mathrm{H}$ COSY correlation of $\mathrm{H}-9$ with $\mathrm{H}-10$, HMBC correlations of $\mathrm{H}-9$ with $\mathrm{C}-1 / \mathrm{C}-10 / \mathrm{C}-11$, and both $\mathrm{H}_{3}-12$ and $\mathrm{H}_{3}-13$ with $\mathrm{C}-1 / \mathrm{C}-10 / \mathrm{C}-11$, produced a four membered carbon ring of $\mathrm{C}-1 / \mathrm{C}-9 / \mathrm{C}-10 / \mathrm{C}-11$ with two tertiary methyls attached. The last ring, the nine-membered macrocyclic moiety for caryophyllene-type sesquiterpene, was deduced by ${ }^{1} \mathrm{H}-{ }^{1} \mathrm{H}$ COSY correlation of $\mathrm{H}-2$ with $\mathrm{H}-3$, HMBC correlations of $\mathrm{H}-9$ with $\mathrm{C}-2$ and $\mathrm{H}-3$ with $\mathrm{C}-4 / \mathrm{C}-5$, and some of the above ${ }^{1} \mathrm{H}^{-}{ }^{1} \mathrm{H}$ COSY and HMBC signals. Subsequently, an acetoxyl was attached to C-2 by H-2 correlating with carbonyl at $\delta_{\mathrm{C}} 170.4$ in HMBC. A methyl was attached to C- 4 by $\mathrm{H}_{3}-15$ correlating with C-3/C-4/C-5. The HMBC correlations of methoxyl at $\delta_{\mathrm{H}} 3.36$ with C-6 and methoxyl at $\delta_{\mathrm{H}} 3.27$ with C-7 located two methoxyls at C6 and C-7, respectively. Taking into account the molecular formula and the chemical shift of $\mathrm{C}-4$, there should be a hydroxyl at C-4. The relative configuration of 1 was determined by ROESY experiment (Fig. 2). The ROESY correlations of $\mathrm{H}-2$ with $\mathrm{H}-9 / \mathrm{H}_{3}-13, \mathrm{H}-9$ with $\mathrm{H}-6$, and $\mathrm{H}-6$ with $\mathrm{H}_{3}-15$ suggested that $\mathrm{H}-2, \mathrm{H}-6, \mathrm{H}-9, \mathrm{H}_{3}-13$ and $\mathrm{H}_{3}-15$ had the relative configuration of $\alpha$. Whereas, the ROESY correlations of $\mathrm{H}-5$ with $\mathrm{H}-14 / \mathrm{H}-$ 7, $\mathrm{H}-14$ with $\mathrm{H}-8, \mathrm{H}-7$ with $\mathrm{CH}_{3} \mathrm{O}-6$ revealed that $\mathrm{H}-5, \mathrm{H}-7, \mathrm{H}-8$ and $\mathrm{H}-14$ had the relative configuration of $\beta$ (Fig. 2). The absolute configuration of $\mathbf{1}$ was determined by single crystal X-
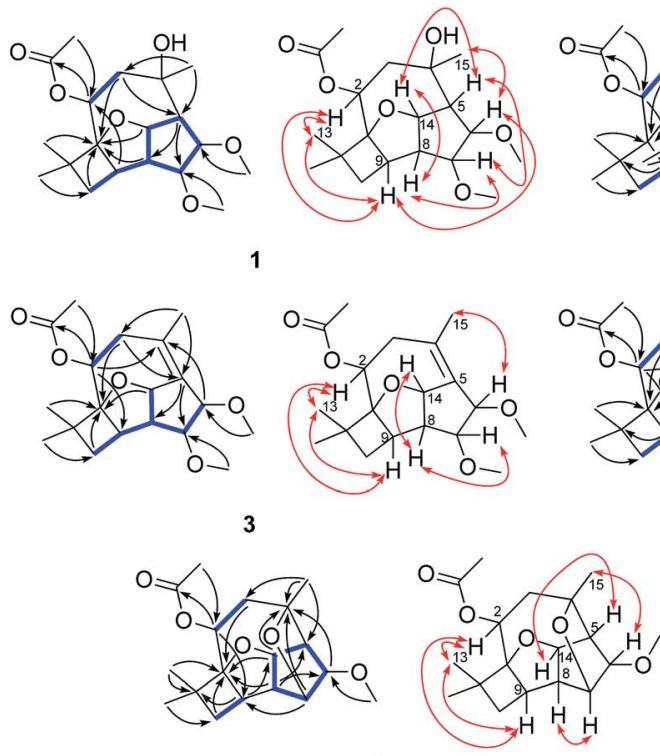

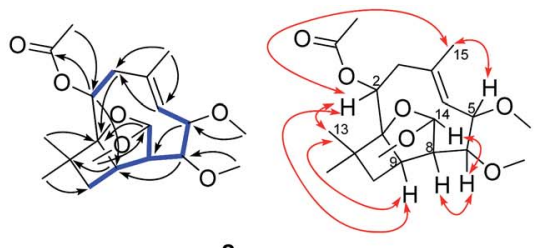

2
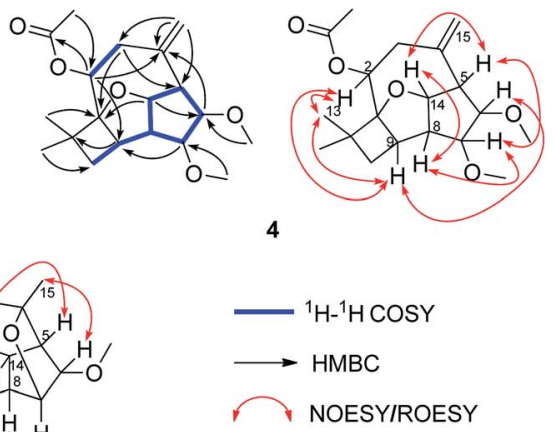

Fig. 2 The ${ }^{1} \mathrm{H}-{ }^{1} \mathrm{H}$ COSY, key HMBC and NOESY/ROESY correlations of compounds 1-5. 
ray diffraction, a suitable low Flack parameter 1.1(10) effectively suggested 1 as $1 S, 2 S, 4 R, 5 R, 6 R, 7 R, 8 S, 9 R, 14 S$ (Fig. 3). Therefore, 1 was elucidated and named as pestalotiopsin D.

Pestalotiopsin E (2), obtained as a colorless oil, had a molecular formula of $\mathrm{C}_{20} \mathrm{H}_{32} \mathrm{O}_{6}$ with five degrees of unsaturation based on its HRESIMS analysis $\left(\mathrm{m} / \mathrm{z} 391.2090[\mathrm{M}+\mathrm{Na}]^{+}\right.$, calcd for 391.2096). The ${ }^{1} \mathrm{H}$ NMR (Table 1) spectrum revealed that 2 had three methoxyls $\left[\delta_{\mathrm{H}} 3.27\left(3 \mathrm{H}, \mathrm{s}, \mathrm{OCH}_{3}-6\right), 3.38(3 \mathrm{H}, \mathrm{s}\right.$, $\left.\left.\mathrm{OCH}_{3}-7\right), 3.50\left(3 \mathrm{H}, \mathrm{s}, \mathrm{OCH}_{3}-14\right)\right]$, four tertiary methyls $\left[\delta_{\mathrm{H}} 1.09\right.$ (3H, s, $\left.\mathrm{H}_{3}-12\right)$, 1.01 (3H, s, $\left.\mathrm{H}_{3}-13\right), 1.87$ (3H, s, $\left.\mathrm{H}_{3}-15\right), 2.05$ (3H, s, OAc)], one olefinic methine $\left[\delta_{\mathrm{H}} 5.14(1 \mathrm{H}, \mathrm{d}, J=11.8 \mathrm{~Hz}, \mathrm{H}-5)\right]$ and four oxygenated methines $\left[\delta_{\mathrm{H}} 5.22(1 \mathrm{H}, \mathrm{dd}, J=10.7 /\right.$ $5.6 \mathrm{~Hz}, \mathrm{H}-2), 3.94$ (1H, dd $J=11.8 / 5.1 \mathrm{~Hz}, \mathrm{H}-6), 3.52(1 \mathrm{H}, \mathrm{dd}, J=$ 5.2/2.8 Hz, H-7), 5.28 (1H, d, $J=2.4 \mathrm{~Hz}, \mathrm{H}-14)]$. The ${ }^{13} \mathrm{C}$ NMR (Table 2), along with DEPT 135 and HSQC, revealed the existence of twenty carbon atoms including one acetoxyl (for its methyl and carbonyl), three methoxyls, three tertiary methyls, two methylenes, seven methines (one olefinic and four oxygenated), and three quaternary carbons (one olefinic). One acetoxyl and one double bond accounting for two of the five indices of unsaturation illustrated the presence of a tricyclic ring system. All the proton signals were well assigned to their relevant carbons by HSQC experiment. The ${ }^{1} \mathrm{H}-{ }^{1} \mathrm{H}$ COSY spectrum established two isolated systems (Fig. 2). Comparing the NMR data of 2 with those of $\mathbf{1}$, revealed that they possessed identical carbon skeleton, with the only difference for C-4 $\left(\delta_{\mathrm{C}}\right.$ 136.3 in 2, 74.6 in 1), C-5 and $\mathrm{H}-5\left(\delta_{\mathrm{C}} 125.4\right.$ and $\delta_{\mathrm{H}} 5.14$ in 2, $\delta_{\mathrm{C}}$ 56.8 and $\delta_{\mathrm{H}} 2.28$ in 1), and $\mathrm{C}-14$ and $\mathrm{H}-14\left(\delta_{\mathrm{C}} 115.1\right.$ and $\delta_{\mathrm{H}} 5.28$ in $2, \delta_{\mathrm{C}} 84.5$ and $\delta_{\mathrm{H}} 5.02$ in 1). Clearly, there should be a double bond produced between $\mathrm{C}-4$ and $\mathrm{C}-5$ in 2 . The much downfield chemical shift of C-14 indicated that it was di-oxygenated. The HMBC correlation of $\mathrm{H}-2$ with carbonyl located the acetoxyl at C2. The HMBC correlations of methoxyl at $\delta_{\mathrm{H}} 3.27$ with C-6, methoxyl at $\delta_{\mathrm{H}} 3.38$ with $\mathrm{C}-7$, and methoxyl at $\delta_{\mathrm{H}} 3.50$ with C14 located three methyls at C-6, C-7 and C-14, respectively. $\mathrm{H}_{3}$ 12, $\mathrm{H}_{3}-13$, and $\mathrm{H}_{3}-15$ were also located by $\mathrm{HMBC}$ correlations (Fig. 2). ROESY correlations of $\mathrm{H}-2$ with $\mathrm{H}_{3}-13 / \mathrm{H}-9 / \mathrm{H}_{3}-15$, and $\mathrm{H}_{3}-15$ with $\mathrm{H}-6$ suggested that $\mathrm{H}-2, \mathrm{H}-6, \mathrm{H}-9, \mathrm{H}_{3}-13$ and $\mathrm{H}_{3}-15$ had the relative configuration of $\alpha$. ROESY correlations of $\mathrm{H}-14$ with $\mathrm{H}-7 / \mathrm{H}-8$ revealed that $\mathrm{H}-7, \mathrm{H}-8$ and $\mathrm{H}-14$ had the relative configuration of $\beta$. No observation of ROESY correlation between $\mathrm{H}-5$ with $\mathrm{H}_{3}-15$ indicated a E-geometry for the double bond $^{7}$ (Fig. 2). At last, 2 was elucidated and named as pestalotiopsin E.

Pestalotiopsin F (3), obtained as a colorless oil, had a molecular formula of $\mathrm{C}_{19} \mathrm{H}_{28} \mathrm{O}_{5}$ with six degrees of unsaturation based on its HRESIMS analysis $\left(\mathrm{m} / \mathrm{z} 359.1834[\mathrm{M}+\mathrm{Na}]^{+}\right.$, calcd for 359.1834), which was 18 atomic mass units less than that of pestalotiopsin D (1). Comparing the NMR data of 3 (Tables 1 and 2) with those of $\mathbf{1}$ and on the basis of its ${ }^{1} \mathrm{H}-{ }^{1} \mathrm{H}$ COSY and HMBC (Fig. 2) revealed that they possessed identical carbocyclic cores. The difference was the one side oxygenated single bond between C-4 $\left(\delta_{\mathrm{C}} 74.6\right)$ and $\mathrm{C}-5\left(\delta_{\mathrm{C}} 56.8\right.$ and $\left.\delta_{\mathrm{H}} 2.88\right)$ in 1 transferred to a non-oxygenated double bond $\left(\delta_{\mathrm{C}} 129.7\right.$ for C-4 and 133.8 for C-5) in 3, it was clear that 1 experienced the loss of a $\mathrm{H}_{2} \mathrm{O}$, this was also supported by the molecular weight difference between 1 and 3. ROESY correlations of $\mathrm{H}-2$ with $\mathrm{H}_{3}$ 13/H-9 and $\mathrm{H}_{3}-15$ with $\mathrm{H}-6$ but no correlation of $\mathrm{H}-6$ with $\mathrm{H}-7$ suggested that $\mathrm{H}-2, \mathrm{H}-6, \mathrm{H}-9, \mathrm{H}_{3}-13$ and $\mathrm{H}-15$ had the relative configuration of $\alpha$. ROESY correlations of $\mathrm{H}-14$ with $\mathrm{H}-7 / \mathrm{H}-8$ revealed that $\mathrm{H}-7, \mathrm{H}-8$ and $\mathrm{H}-14$ had the relative configuration of $\beta$ (Fig. 2). Finally, 3 was elucidated and named as pestalotiopsin F.

Pestalotiopsin G (4), obtained as white power. Based on the HRESIMS analysis $\left(\mathrm{m} / z\right.$ 359.1833 $[\mathrm{M}+\mathrm{Na}]^{+}$, calcd for 359.1834) and the ${ }^{13} \mathrm{C}$ NMR data, the molecular formula of was established as $\mathrm{C}_{19} \mathrm{H}_{28} \mathrm{O}_{5}$ with six degrees of unsaturation. The NMR data of 4 (Tables 1 and 2) revealed that it had the similar structure with 3 , the largest variation being at C-5 (from $\delta_{\mathrm{C}} 133.8$ in 3 to $\delta_{\mathrm{C}} 56.9$ in 4 ) and C-15 (from $\delta_{\mathrm{C}} 22.1$ for a methyl in 3 to $\delta_{\mathrm{C}}$ 118.3 for a terminal vinyl in 4), implying that the double bond between C-4 and C-5 in 3 fused to a terminal double bond between C-4 and C-15 in 4 (Fig. 2), this was also supported by HMBC correlations (Fig. 2). The NOESY experiment analysis (Fig. 2) indicated that $\mathrm{H}-2, \mathrm{H}-9, \mathrm{H}-6$ and $\mathrm{H}_{3}-13$ had the relative configuration of $\alpha$, whereas $\mathrm{H}-5, \mathrm{H}-7, \mathrm{H}-8$ and $\mathrm{H}-14$ had the relative configuration of $\beta$. Finally, 4 was elucidated and named as pestalotiopsin $\mathrm{G}$.

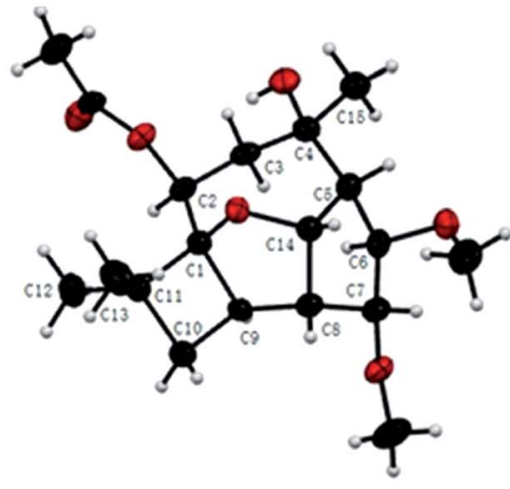

1

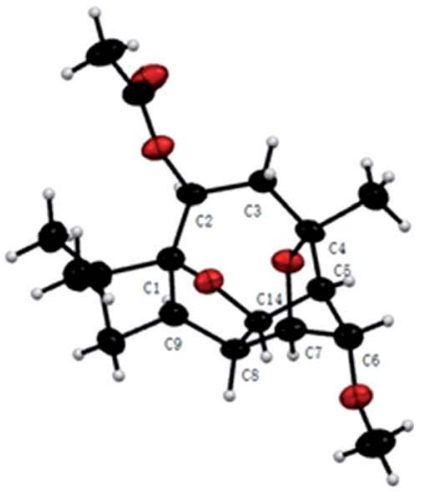

5

Fig. 3 The ORTEP diagrams of compounds 1 and 5 . 
Table $3{ }^{1} \mathrm{H}$ NMR data $(400 \mathrm{MHz})$ and ${ }^{13} \mathrm{C}$ NMR data $(100 \mathrm{MHz})$ data of compounds $6^{a}$ and $7^{b}\left({ }^{a}\right.$ in $\mathrm{CDCl}_{3},{ }^{b}$ in $\mathrm{CD}_{3} \mathrm{OD}-d_{4}, \delta$ in ppm, $J$ in $\mathrm{Hz}$ )

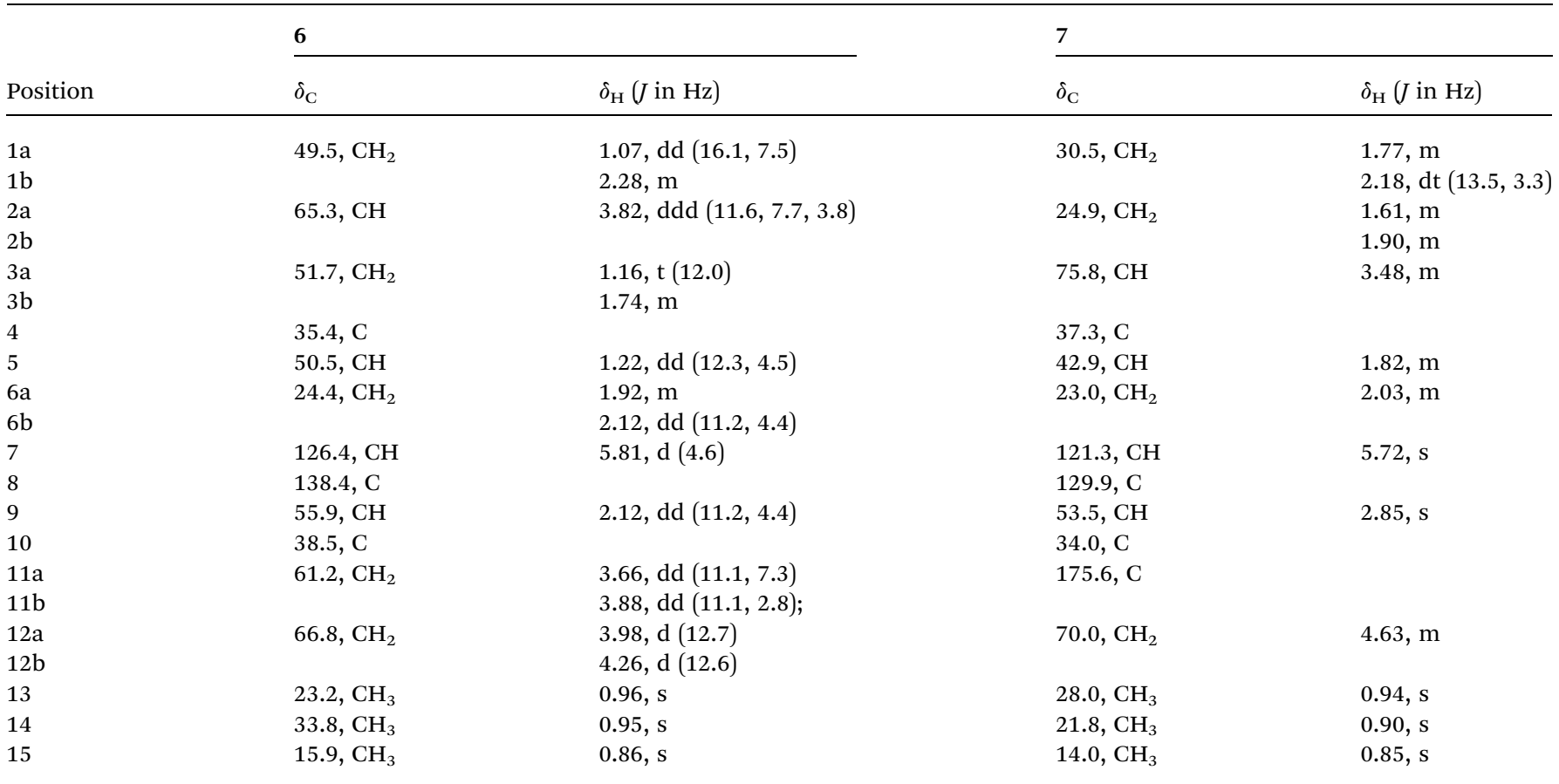

Pestalotiopsin $\mathrm{H}$ (5) was isolated as colorless oil, its molecular formula was established as $\mathrm{C}_{18} \mathrm{H}_{26} \mathrm{O}_{5}$ with six degrees of unsaturation by the quasi-molecular ion at $m / z 345.1674[\mathrm{M}+$ $\mathrm{Na}]^{+}$(calcd for 345.1678) in the HRESIMS, which was 32 atomic mass units fewer than 1 . The ${ }^{1} \mathrm{H}$ and ${ }^{13} \mathrm{C}$ NMR spectroscopic data (Tables 1 and 2) revealed $\mathbf{5}$ had a very similar structural feature to 1 . The difference of the downfield shift for C-4 (from $\delta_{\mathrm{C}} 74.6$ in 1 to $\delta_{\mathrm{C}} 79.8$ in 5), the upfield shift for C-7 (from $\delta_{\mathrm{C}} 85.9$ in 1 to $\delta_{\mathrm{C}} 77.0$ in 5), and the downfield shift for $\mathrm{H}-7$ (from $\delta_{\mathrm{H}} 3.66$ in 1 to $\delta_{\mathrm{H}} 3.97$ in 5) were observed. For 5, the HMBC (Fig. 2) correlation between $\mathrm{H}-7$ and $\mathrm{C}-4$, and 32 atomic mass units less than 1, indicated that 1 experienced the loss of a $\mathrm{CH}_{3} \mathrm{OH}$ molecule to produce $\mathbf{5}$. The relative configuration of $\mathbf{5}$ was assigned by NOESY experiment (Fig. 2). The structure and spectral data of $\mathbf{5}$ were consistent with a synthetic intermediate in the literature ${ }^{25}$ and therefore it was deduced as a new natural product and named as pestalotiopsin $\mathrm{H}$. Its absolute configuration $(1 S, 2 S, 4 S, 5 R, 6 R, 7 R, 8 S, 9 R, 14 S)$ was identified by single-crystal X-ray crystallographic analysis with a suitable low Flack parameter 0.02(11) (Fig. 3).

Pestalotiophol A (6), obtained as a colorless oil, had a molecular formula of $\mathrm{C}_{15} \mathrm{H}_{26} \mathrm{O}_{3}$ with three degrees of unsaturation based on its HRESIMS analysis $\left(\mathrm{m} / \mathrm{z} 277.1779[\mathrm{M}+\mathrm{Na}]^{+}\right.$, calcd for 277.1779) and ${ }^{13} \mathrm{C}$ NMR data. The ${ }^{1} \mathrm{H}$ NMR (Table 3) spectrum revealed that 6 had three tertiary methyls $\left[\delta_{\mathrm{H}} 0.95\right.$ (3H, s, $\left.\mathrm{H}_{3}-14\right), 0.96$ (3H, s, $\left.\mathrm{H}_{3}-13\right), 0.86$ (3H, s, $\left.\mathrm{H}_{3}-15\right)$ ], two monooxygenated methylenes $\left[\delta_{\mathrm{H}} 3.66(1 \mathrm{H}, \mathrm{dd}, J=11.1 / 7.3 \mathrm{~Hz}, \mathrm{H}-11 \alpha)\right.$, $3.88(1 \mathrm{H}, \mathrm{dd}, J=11.1 / 2.8 \mathrm{~Hz}, \mathrm{H}-11 \beta) ; 4.26(1 \mathrm{H}, \mathrm{d}, J=12.6 \mathrm{~Hz}, \mathrm{H}-$ $12 \alpha), 3.98(1 \mathrm{H}, \mathrm{d}, J=12.7 \mathrm{~Hz}, \mathrm{H}-12 \beta)]$, one olefinic proton $\left[\delta_{\mathrm{H}}\right.$ $5.81(1 \mathrm{H}, \mathrm{d}, J=4.6 \mathrm{~Hz}, \mathrm{H}-7)]$, one mono-oxygenated methine $\left[\delta_{\mathrm{H}}\right.$ $3.82(1 \mathrm{H}, \mathrm{ddd}, J=11.6 / 7.7 / 3.8 \mathrm{~Hz}, \mathrm{H}-2 \alpha)]$, and two non- oxygenated methines $\left[\delta_{\mathrm{H}} 2.12(1 \mathrm{H}, \mathrm{dd}, J=11.2 / 4.4 \mathrm{~Hz}, \mathrm{H}-9 \alpha)\right.$, $1.22(1 \mathrm{H}, \mathrm{dd}, J=12.3 / 4.5 \mathrm{~Hz}, \mathrm{H}-5 \alpha)]$. The ${ }^{13} \mathrm{C}$ NMR (Table 3 ) spectrum showed fifteen carbon signals. Combined with the DEPT 135 and HSQC experiments, these carbons were classified into three methyls, five methylenes (two mono-oxygenated), four methines (one mono-oxygenated and one olefinic), and three quaternary carbons (one olefinic). The proton resonances were well assigned to relevant carbon atoms by HSQC. The ${ }^{1} \mathrm{H}$ and ${ }^{13} \mathrm{C}$ NMR signals were characteristic for the structures of drimane-type sesquiterpenes with 6/6-fused ring system. ${ }^{32}$ The ${ }^{1} \mathrm{H}-{ }^{1} \mathrm{H}$ COSY correlations established two isolated systems (Fig. 4). The downfield chemical shifts for C-2 at $\delta_{\mathrm{C}} 65.3, \mathrm{C}-11$ at $\delta_{\mathrm{C}} 61.2$, and $\mathrm{C}-12$ at $\delta_{\mathrm{C}} 66.8$ implied that there should be three hydroxyls attached to $\mathrm{C}-2, \mathrm{C}-13$ and $\mathrm{C}-14$, respectively, this result was also supported by the HRESIMS data. NOESY signals (Fig. 4) of $\mathrm{H}_{3}-15$ with $\mathrm{H}_{2}-11 / \mathrm{H}_{3}-13$ and $\mathrm{H}_{3}-13$ with $\mathrm{H}-2$ indicated that $\mathrm{H}_{3}-15, \mathrm{H}_{2}-11, \mathrm{H}_{3}-13$ and $\mathrm{H}-2$ had the relative configuration

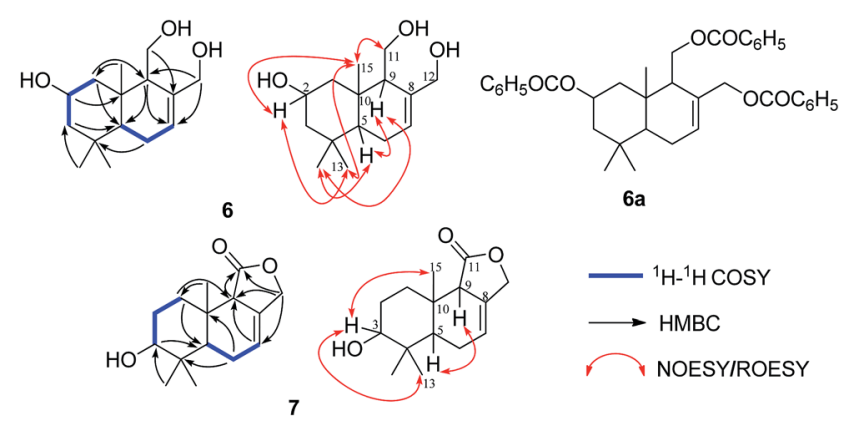

Fig. 4 The ${ }^{1} \mathrm{H}-{ }^{1} \mathrm{H}$ COSY, key $\mathrm{HMBC}$ and NOESY/ROESY correlations of compounds 6 and 7 and the structure of compound $6 a$. 


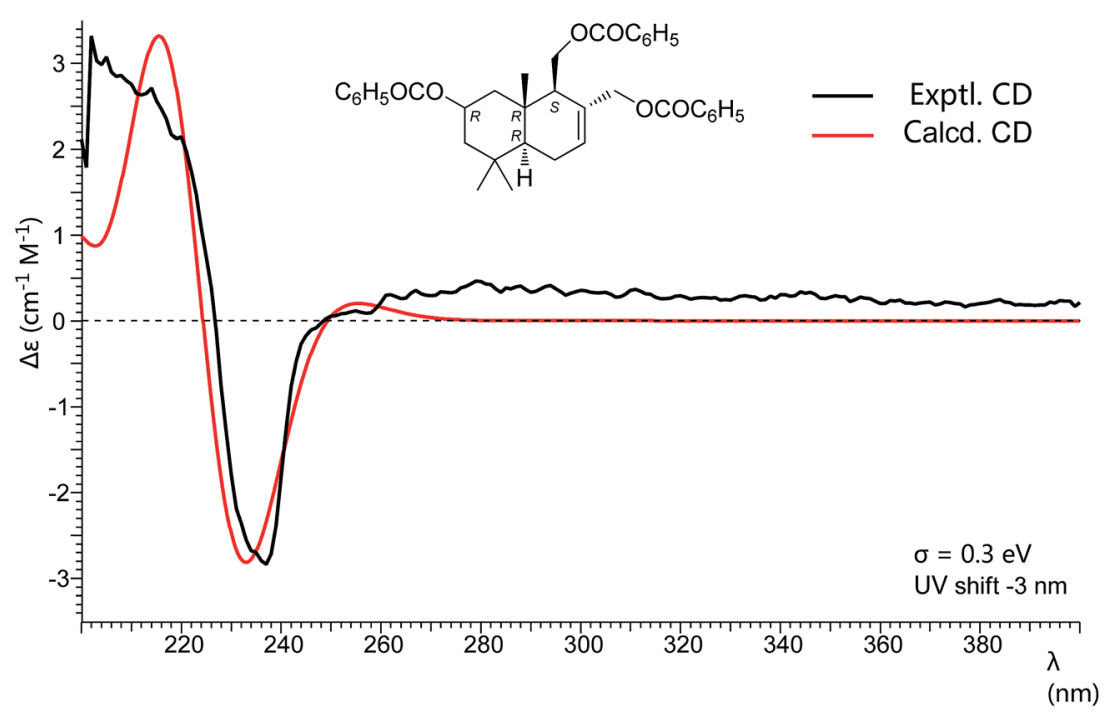

Fig. 5 Experimental and calculated CD spectra of compound $6 a$.

of $\beta$. NOESY signals (Fig. 4 ) of $\mathrm{H}-9$ with $\mathrm{H}-5 / \mathrm{H}_{3}-14$ indicated that $\mathrm{H}-9, \mathrm{H}-5$ and $\mathrm{H}_{3}-14$ had the relative configuration of $\alpha$. To determine the absolute configuration of $\mathbf{6}$, its fully benzoylated derivative 6a (Fig. 4) was prepared. The absolute configuration of 6a was determined to be $2 R, 5 R, 9 S$ and $10 R$ by its CD spectrum (Fig. 5) associated with TD-DFT calculation. So, the absolute configuration of $\mathbf{6}$ was $2 R, 5 R, 9 S$ and $10 R$, same to $6 \mathbf{a}$. Thus, 6 was elucidated and named as pestalotiophol A.

Pestalotiophol B (7) was isolated as colorless oil. The quasimolecular ion at $m / z 273.1464[\mathrm{M}+\mathrm{Na}]^{+}$(calcd for 273.1466) by HRESIMS indicated the molecular formula of 7 was $\mathrm{C}_{15} \mathrm{H}_{22} \mathrm{O}_{3}$ with five degrees of unsaturation. The ${ }^{13} \mathrm{C}$ NMR (Table 3), with DEPT 135 together, showed fifteen carbons including one carbonyl, two olefinic carbons, four aliphatic methylenes, three aliphatic methines, and three methyl carbons. The ${ }^{1} \mathrm{H}$ NMR spectrum (Table 3) revealed that 7 had one olefinic proton $\left[\delta_{\mathrm{H}}\right.$ $5.72(1 \mathrm{H}, \mathrm{s}, \mathrm{H}-7)]$, one oxygenated methine $\left[\delta_{\mathrm{H}} 3.48(1 \mathrm{H}, \mathrm{m}, \mathrm{H}-3)\right]$, one oxygenated methylene $\left[\delta_{\mathrm{H}} 4.63(2 \mathrm{H}, \mathrm{m}, \mathrm{H}-12)\right]$ and three tertiary methyls $\left[\delta_{\mathrm{H}} 0.94\left(3 \mathrm{H}, \mathrm{s}, \mathrm{H}_{3}-13\right), 0.90\left(3 \mathrm{H}, \mathrm{s}, \mathrm{H}_{3}-14\right), 0.85\right.$ $\left.\left(3 \mathrm{H}, \mathrm{s}, \mathrm{H}_{3}-15\right)\right]$. The proton resonances were distinctly assigned to relevant carbon atoms by HSQC. The ${ }^{1} \mathrm{H}$ NMR and ${ }^{13} \mathrm{C}$ NMR data indicated that 7 was characteristic of the drimane-type sesquiterpene with 6/6/5-fused ring system. ${ }^{34}$ The ${ }^{1} \mathrm{H}^{-1} \mathrm{H}$ COSY (Fig. 4) showed two isolated spin systems (Fig. 4). The HMBC correlations of $\mathrm{H}-9$ with $\mathrm{C}-7 / \mathrm{C}-8$, and $\mathrm{H}-7$ with $\mathrm{C}-8 / \mathrm{C}-9$, located a double bond of $\mathrm{C}-7 / \mathrm{C}-8$, a hydroxyl was located at $\mathrm{C}-3$ by considering the molecular formula and the downfield chemical shift of C-3. OH-3 and double bond of C-7 and C-8 in 7 were two differences between 7 and one reported drimane-type sesquiterpene in the literature. ${ }^{34}$ ROESY correlations (Fig. 4) of $\mathrm{H}_{3}-15$ with $\mathrm{H}-3 / \mathrm{H}_{3}-13$ indicated that $\mathrm{H}_{3}-15, \mathrm{H}_{3}-13$ and $\mathrm{H}-3$ had the relative configuration of $\beta$. ROESY correlation (Fig. 4) of $\mathrm{H}-9$ with $\mathrm{H}-5$ indicated that H-9 and H-5 had the relative configuration of $\alpha$. Finally, 7 was elucidated and named as pestalotiophol B.

Compounds 1-15 were evaluated in vitro against cancer cell lines A549, HeLa, and SMMC-7721 by MTT assay. Compound 8 exhibited the strongest cytotoxicity against SMMC-7721 with an
$\mathrm{IC}_{50}$ value of $28.3 \mu \mathrm{M}$, which is comparable to that of the positive control etoposide $\left(\mathrm{IC}_{50}\right.$ of $23.2 \mu \mathrm{M}$ ), while it displayed moderate activity against A459 and Hela with $\mathrm{IC}_{50}$ values of 49.3 and $33.3 \mu \mathrm{M}$, respectively. Compound 9 showed the moderate activity against all three cell lines of A549, HeLa, and SMMC7721 with IC $_{50}$ values of $61.9,42.9$, and $44.7 \mu \mathrm{M}$, respectively. Unfortunately, the remaining compounds were inactive.

\section{Experimental}

\section{General experimental procedures}

${ }^{1} \mathrm{H},{ }^{13} \mathrm{C}$, and 2D NMR data were measured on an Agilent DD2 400-MR NMR spectrometer (Agilent Technologies Inc, Santa Clara, United States), and the chemical shifts were referenced to the residual solvent peaks. IR spectra were measured with a Bruker Tensor 27 spectrophotometer in $\mathrm{KBr}$ pellets. HR-ESIMS data were obtained by an AB Sciex Triple TOF® 4600 system. UV spectra were recorded on an UV-2550 UV/Vis spectrophotometer (Shimadzu Corporation, Tokyo, Japan). CD spectra were measured on a JASCO J-810 spectrometer in $n$ hexane and CD calculation was carried out by TD-DFT method with cam-B3LYP/TZVP level. The analytical and semipreparative HPLC were performed on a Waters HPLC system, which was equipped with a W1525 Binary pump, a W2998 photodiode array detector, a W1500-CH column compartment, and a W2707 auto sampler using a Waters XBridge C18 column $(4.6 \times 250 \mathrm{~mm}, 5 \mu \mathrm{m})$ and Waters XBridge C18 column $(10 \times$ $250 \mathrm{~mm}, 5 \mu \mathrm{m}$ ) (Waters Corporation, Milford, MA, USA). Preparative HPLC was performed on an Agilent 1260 series HPLC (Agilent Technologies Inc, Santa Clara, United States), which was equipped with a 1260 pump and a 1260 diode array detector using a Waters XBridge C18 column $(19 \mathrm{~mm} \times 250$ $\mathrm{mm}, 5 \mu \mathrm{m}$ ) eluted by $\mathrm{MeCN} / \mathrm{H}_{2} \mathrm{O}$ system, flow rate was $15 \mathrm{~mL}$ $\min ^{-1}$. The medium-pressure liquid chromatography (MPLC) apparatus used was equipped with a dual-pump gradient system, and a UV preparative detector (Buchi Inc, Swiss Confederation). Silica gels $(200-300,300-400$ and $230-400$ 
mesh) used for column chromatographies were from Qingdao Haiyang Chemical Company Ltd., Qingdao, China, and from Merck, Darmstadt, Germany. Sephadex LH-20 used for column chromatographies was from GE Healthcare Life Sciences (GE).

\section{Fungal material}

The strain numbered HM-5 was isolated from stem bark of Sinopodophyllum hexandrum (Royle) Ying. collected from Qinling mountains, and was deposited at Shaanxi Key Laboratory of Phytochemistry, Baoji University of Arts and Sciences. The strain was identified as Pestalotiopsis adusta based on the morphological characteristics.

\section{Fermentation and cultivation}

The strain was grown on a plate of potato dextrose medium consisting of $20 \mathrm{~g}$ glucose, $200 \mathrm{~g}$ potato, and $20 \mathrm{~g}$ agar in 1000 $\mathrm{mL}$ distilled water. After 7 days inoculation at $28^{\circ} \mathrm{C}$, a mycelium was inoculated into each of the $100 \mathrm{~mL}$ erlenmeyer flasks containing $30 \mathrm{~mL}$ of liquid PD medium consisting of $20 \mathrm{~g}$ glucose and $200 \mathrm{~g}$ potato in $1000 \mathrm{~mL}$ distilled water to obtain the seed strain. The flasks were incubated at $28{ }^{\circ} \mathrm{C}$ on a rotary shaker $(120 \mathrm{rpm})$ for 3 days. A suspension $(500 \mu \mathrm{L})$ of the seed liquid was inoculated aseptically to $500 \mathrm{~mL}$ Erlenmeyer flasks each containing $40 \mathrm{~g}$ rice and $60 \mathrm{~mL}$ distilled water, a total of 200 flasks. The flasks were incubated at $28{ }^{\circ} \mathrm{C}$ for 30 days.

\section{Extraction and isolation}

After fermentation, the culture was extracted by ultrasonic with methanol. The extracting solution was evaporated to remaining $10 \mathrm{~L}$ aqueous extract. Then the aqueous extract was degreased with petroleum ether, concentrated and extracted thoroughly with EtOAc. Combined the EtOAc solvent and then evaporated under vacuum to afford a crude extract (111.8 g). Then the crude extract (111.8 g) was subjected to silica gel CC using a successive elution of petroleum ether-ethyl acetate (99:1, $50: 1,20: 1$; $10: 1,8: 1,4: 1,2: 1,1: 1,1: 2$ and $0: 100, \mathrm{v} / \mathrm{v}$ ) to afford eight fractions (Fr1 to Fr8). Fr3 (10.6 g) was separated by repeated CC on silica gel, Sephadex LH-20, to yield 10 (3.2 g). Fr4 (6.3 g) was subjected to Sephadex LH-20 CC using $\mathrm{MeOH}$ to give three fractions (Fr4-1 to Fr4-3). Fr4-2 (3.6 g) was further subjected to MPLC on ODS RP-C18 CC, then purified with silica gel CC and Sephadex LH-20 gel, to afford 1 (9.8 mg), 2 (8.0 mg), 3 (20.1 mg), $8(100.6 \mathrm{mg})$, and 9 (305.7 mg). Fr5 (24.9 g) was subjected to repeated CC on silica gel and Sephadex $\mathrm{LH}-20$, then followed by recrystallization, to yield $4(100.8 \mathrm{mg}), 5(20.4 \mathrm{mg}), 12(30.2 \mathrm{mg})$, $13(150.2 \mathrm{mg})$, and 15 (26.0 mg). Fr6 (7.7 g) was subjected to MPLC on ODS RP-C18 CC, and then subjected to HPLC using MeCN- $\mathrm{H}_{2} \mathrm{O}(30: 70, \mathrm{v} / \mathrm{v})$ at a flow rate of $15 \mathrm{~mL} \mathrm{~min}{ }^{-1}$ to yield 6 $\left(t_{\mathrm{R}}: 10.1 \mathrm{~min}, 12.6 \mathrm{mg}\right), 14\left(t_{\mathrm{R}}: 12.7 \mathrm{~min} 50.3 \mathrm{mg}\right)$, and $7\left(t_{\mathrm{R}}\right.$ : $16.0 \mathrm{~min}, 3.0 \mathrm{mg})$. Fr7 $(5.3 \mathrm{~g})$ was separated by repeated CC on silica gel and Sephadex $\mathrm{LH}-20$, then purified on semipreparative RP-HPLC using $\mathrm{CH}_{3} \mathrm{CN}-\mathrm{H}_{2} \mathrm{O}(40: 60$, v/v) at a flow

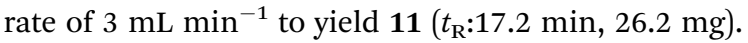

Pestalotiopsin D (1). White amorphous powder; $[\alpha]_{\mathrm{D}}^{20}-9.7(c$ 0.15, $\mathrm{CDCl}_{3}$ ); UV (MeOH) $\lambda_{\max }(\log \varepsilon) 244$ (2.25), 290 (2.85), 652 (3.29) nm; IR (KBr) $\nu_{\max } 3012,2970,2924,1719,1439,1244$,
1122, 1028, $908 \mathrm{~cm}^{-1} ;{ }^{1} \mathrm{H}$ and ${ }^{13} \mathrm{C}$ NMR data $\left(\mathrm{CDCl}_{3}\right)$, see Tables 1 and 2; HRESIMS $\mathrm{m} / z$ 377.1931 $[\mathrm{M}+\mathrm{Na}]^{+}$(calcd for $\left.\mathrm{C}_{19} \mathrm{H}_{30} \mathrm{O}_{6} \mathrm{Na}^{+}, 377.1940\right)$.

Pestalotiopsin E (2). Colorless oil; $[\alpha]_{\mathrm{D}}^{20}+10.4\left(c 0.11, \mathrm{CDCl}_{3}\right)$; $\mathrm{UV}(\mathrm{MeOH}) \lambda_{\max }(\log \varepsilon) 290$ (2.80), 652 (3.35) nm; IR (KBr) $\nu_{\max }$ 2928, 1736, 1454, 1375, 1242, 1091, 1018, $969 \mathrm{~cm}^{-1} ;{ }^{1} \mathrm{H}$ and ${ }^{13} \mathrm{C}$ NMR data $\left(\mathrm{CDCl}_{3}\right)$, see Tables 1 and 2; HRESIMS $\mathrm{m} / z 391.2090$ $[\mathrm{M}+\mathrm{Na}]^{+}$(calcd for $\mathrm{C}_{20} \mathrm{H}_{32} \mathrm{O}_{6} \mathrm{Na}^{+}, 391.2096$ ).

Pestalotiopsin F (3). Colorless oil; $[\alpha]_{\mathrm{D}}^{20}+33.4\left(c 0.11, \mathrm{CDCl}_{3}\right)$; $\mathrm{UV}(\mathrm{MeOH}) \lambda_{\max }(\log \varepsilon) 290$ (2.67), $652(3.30) \mathrm{nm}$; IR (KBr) $\nu_{\max }$ 2930, 2867, 1734, 1455, 1370, 1241, 1098, 1021, $955 \mathrm{~cm}^{-1} ;{ }^{1} \mathrm{H}$ and ${ }^{13} \mathrm{C}$ NMR data $\left(\mathrm{CDCl}_{3}\right)$, see Tables 1 and 2; HRESIMS $\mathrm{m} / \mathrm{z}$ $359.1834[\mathrm{M}+\mathrm{Na}]^{+}$(calcd for $\mathrm{C}_{19} \mathrm{H}_{28} \mathrm{O}_{5} \mathrm{Na}^{+}, 359.1834$ ).

Pestalotiopsin G (4). White power; $[\alpha]_{\mathrm{D}}^{20}+5.6\left(c 0.11, \mathrm{CDCl}_{3}\right)$; $\mathrm{UV}(\mathrm{MeOH}) \lambda_{\max }(\log \varepsilon) 290$ (2.76), 652 (3.31) nm; IR (KBr) $\nu_{\max }$ 2955, 2927, 2867, 1725, 1442, 1372, 1246, 1102, 1014, $952 \mathrm{~cm}^{-1}$; ${ }^{1} \mathrm{H}$ and ${ }^{13} \mathrm{C}$ NMR data $\left(\mathrm{CDCl}_{3}\right)$, see Tables 1 and 2 ; HRESIMS $\mathrm{m} / \mathrm{z}$ $359.1833[\mathrm{M}+\mathrm{Na}]^{+}$(calcd for $\mathrm{C}_{19} \mathrm{H}_{28} \mathrm{O}_{5} \mathrm{Na}^{+}, 359.1834$ ).

Pestalotiopsin H (5). Colorless amorphous powder; $[\alpha]_{\mathrm{D}}^{20}+$ 44.6 (c 0.08, $\mathrm{CDCl}_{3}$ ); UV (MeOH) $\lambda_{\max }(\log \varepsilon) 290$ (2.68), 652 (3.29) nm; IR (KBr) $\nu_{\max } 2959,2925,2858,1776,1736,1456$, 1367, 1247, 1085, 1022, $801 \mathrm{~cm}^{-1} ;{ }^{1} \mathrm{H}$ and ${ }^{13} \mathrm{C}$ NMR data $\left(\mathrm{CDCl}_{3}\right)$, see Tables 1 and 2; HRESIMS $m / z$ 345.1674 [M $\left.+\mathrm{Na}\right]^{+}$ (calcd for $\mathrm{C}_{18} \mathrm{H}_{26} \mathrm{O}_{5} \mathrm{Na}^{+}, 345.1678$ ).

Pestalotiophol A (6). Colorless oil; $[\alpha]_{\mathrm{D}}^{20}+49.4(c 0.11, \mathrm{MeOH})$; $\mathrm{UV}(\mathrm{MeOH}) \lambda_{\max }(\log \varepsilon) 290$ (2.79), 652 (3.29) nm; IR (KBr) $\nu_{\max }$ 3333, 2928, 2856, 1460, 1376, 1212, 1147, 1033, $997 \mathrm{~cm}^{-1} ;{ }^{1} \mathrm{H}$ and ${ }^{13} \mathrm{C}$ NMR data $\left(\mathrm{CD}_{3} \mathrm{OD}\right)$, see Table 3; HRESIMS $m / z 277.1779$ $[\mathrm{M}+\mathrm{Na}]^{+}$(calcd for $\mathrm{C}_{15} \mathrm{H}_{26} \mathrm{O}_{3} \mathrm{Na}^{+}, 277.1779$ ).

Pestalotiophol B (7). Colorless oil; $[\alpha]_{\mathrm{D}}^{20}+1.3\left(c 0.11, \mathrm{CDCl}_{3}\right)$; $\mathrm{UV}(\mathrm{MeOH}) \lambda_{\max }(\log \varepsilon) 290$ (2.65), 652 (3.17) nm; IR (KBr) $\nu_{\max }$ 2954, 2923, 2862, 1756, 1687, 1456, 1375, $1018 \mathrm{~cm}^{-1} ;{ }^{1} \mathrm{H}$ and ${ }^{13} \mathrm{C}$ NMR data $\left(\mathrm{CDCl}_{3}\right)$, see Table 3; HRESIMS $\mathrm{m} / z$ 273.1464 [M + $\mathrm{Na}]^{+}$(calcd for $\mathrm{C}_{15} \mathrm{H}_{22} \mathrm{O}_{3} \mathrm{Na}^{+}, 273.1466$ ).

Crystal data for compound 1. $\mathrm{C}_{19} \mathrm{H}_{30} \mathrm{O}_{6}, M_{\mathrm{r}} 354.43$, space group $P 2_{1}, a=5.8418(13) \AA, b=18.700(4) \AA, c=8.9930(15) \AA$, $\alpha=90^{\circ}, \beta=92.986(18)^{\circ}, \gamma=90^{\circ}, V=981.1(3) \AA^{3}, Z=2, M_{\mathrm{u}}=$ $0.088 \mathrm{~mm}^{-1}, D_{\mathrm{X}}=1.200 \mathrm{~g} \mathrm{~cm}^{-3}, F(000)=384.0$; data completeness $=1.54 / 0.80$, theta $(\max )=26.018, R$ indices (all data) $R_{1}=0.0743, \mathrm{w} R_{2}=0.2249$.

Crystal data for compound 5. $\mathrm{C}_{18} \mathrm{H}_{26} \mathrm{O}_{5}, M_{\mathrm{r}} 322.39$, space group $P 2_{1}, a=8.1708(4) \AA, b=18.5668(8) \AA, c=11.4565(6) \AA$, $\alpha=90^{\circ}, \beta=96.846(4)^{\circ}, \gamma=90^{\circ}, V=1725.62(15) \AA^{3}, Z=4, M_{\mathrm{u}}=$ $0.731 \mathrm{~mm}^{-1}, D_{\mathrm{X}}=1.241 \mathrm{~g} \mathrm{~cm}^{-3}, F(000)=696.0$; data completeness $=1.79 / 0.93$, theta $(\max )=71.124, R$ indices (all data) $R_{1}=0.0714, \mathrm{w} R_{2}=0.2210$.

Benzoylation of compound 6. A mixture of compound 6 (2.0 $\mathrm{mg})$, anhydrous pyridine $(3.0 \mathrm{~mL})$ and benzoyl chloride $(5.6 \mathrm{mg})$ were stirred for 2 hours at room temperature. Then the reaction was quenched with deionized water $(5.0 \mathrm{~mL})$, extracted with $\mathrm{CH}_{2} \mathrm{Cl}_{2}(3 \times 5.0 \mathrm{~mL})$. Then the organic layer was washed with water $(3 \times 5.0 \mathrm{~mL})$, dried over $\mathrm{Na}_{2} \mathrm{SO}_{4}$, and evaporated to give crude product. The crude product was then purified by semipreparative HPLC (Waters X Bridge C-18, $250 \times 10 \mathrm{~mm} ; 5 \mu \mathrm{m}$, $\mathrm{MeCN} / \mathrm{H}_{2} \mathrm{O}$ gradient from $18 \%$ to $100 \% \mathrm{MeCN}$ in $30 \mathrm{~min}$ ) to afford compound $\mathbf{6 a}(1.0 \mathrm{mg})$ as a colorless oil; HRESIMS $(\mathrm{m} / \mathrm{z}$ $589.2554[\mathrm{M}+\mathrm{Na}]^{+}$, calcd for $\left.\mathrm{C}_{36} \mathrm{H}_{38} \mathrm{O}_{6} \mathrm{Na}^{+}, 589.2566\right)$. 


\section{$\mathrm{X}$-ray single-crystal diffraction}

Crystals of compounds $\mathbf{1}$ and $\mathbf{5}$ were grown in methanol at room temperature. Crystallographic data for $\mathbf{1}$ were collected on a SuperNova Eos diffractometer with graphite monochromatic $\mathrm{Cu} \mathrm{K} \alpha$ radiation at 297 (2) K. All calculations were performed using SHELXL-97 program. Crystallographic data for $\mathbf{5}$ were collected on a SuperNova Eos diffractometer with graphite monochromatic $\mathrm{Cu} \mathrm{K} \alpha$ radiation at $293 \mathrm{~K}$. All calculations were performed using SHELXL-97 program. $^{35}$ Parameters in CIF format are available as $\mathrm{ESI} \dagger$ from Cambridge Crystallographic Data Centre (pestalotiopsin D (1), CCDC1534582; pestalotiopsin H (5), CCDC1534584).

\section{CD spectrum associated with TD-DFT calculation analysis}

A preliminary conformational search was performed in Conflex6.7 using MMFF94s forcefield. ${ }^{36}$ Conformers were saved and further optimized using the density functional theory (DFT) method and CPCM solvent model at B3LYP/6-31+G (d,p) level in Gaussian 09 software package. ${ }^{37}$ Frequency was calculated at the same level of theory to check optimized results. The stable conformers with populations greater than $1 \%$ and without imaginary frequencies were submitted to ECD calculation by the TDDFT method associated at cam-B3LYP/TZVP level. The excitation energies $(E)$, oscillator strength $(f)$, rotatory strength in velocity form $\left(R_{\mathrm{vel}}\right)$, and rotatory strength in length form $\left(R_{\mathrm{len}}\right)$ of the lowest 32 excited states were calculated. ECD spectra of different conformers were summated in SpecDis according to their Boltzmann-calculated distributions. ${ }^{38}$

\section{Cytotoxicity assay}

The cell viability was determined by the MTT assay. $8 \times 10^{3}$ cells were incubated with the tested compounds in triplicate in 96well plates for $68 \mathrm{~h}$ at $37{ }^{\circ} \mathrm{C}$ in a final volume of $100 \mu \mathrm{L}$. Cells treated with DMSO alone were set as controls. At the end of the treatment, $10 \mu \mathrm{L}$ of MTT ( $5 \mathrm{mg} \mathrm{mL}^{-1}$ ) was added to each well and incubated for an additional $4 \mathrm{~h}$. An extraction buffer (100 $\mu \mathrm{L}, 10 \%$ SDS, $5 \%$ iso-butanol, $0.1 \% \mathrm{HCl}$ ) was added, and the cells were incubated overnight at $37{ }^{\circ} \mathrm{C}$. The viability was calculated by measuring the absorbance at $570 \mathrm{~nm}$ using a microplate reader (BioTek Powerwave XS2, USA).

\section{Acknowledgements}

We gratefully acknowledge financial support from National Natural Science Foundation of China (No. 31600268), Shaanxi Science and Technology Commission (No. 2014JM2058), Shaanxi Education Commission (No. 13JS005), Baoji University of Arts and Sciences (No. ZK15043) and Shaanxi Association for Science and Technology (No. 20150202).

\section{Notes and references}

1 H. B. Bode, B. Bethe, R. Höfs and A. Zeeck, ChemBioChem, 2002, 3, 619-627.

2 J. M. Gao, S. X. Yan and J. C. Qin, Chem. Rev., 2013, 113, 4755-4811.
3 X. L. Yang, J. Z. Zhang and D. Q. Luo, Nat. Prod. Rep., 2012, 29, 622-641.

4 G. Strobel, X. Yang, J. Sears, R. Kramer, R. S. Sidhu and W. M. Hess, Microbiology, 1996, 142, 435-440.

5 S. S. Maharachchikumbura, K. D. Hyde, J. Z. Groenewald, J. Xu and P. W. Crous, Stud. Mycol., 2014, 79, 121-186.

6 K. Wang, J. Lei, J. Wei and N. Yao, Mini-Rev. Med. Chem., 2012, 12, 1382-1393.

7 M. Pulici, F. Sugawara, H. Koshino, J. Uzawa, S. Yoshida, E. Lobkovsky and J. Clardy, J. Org. Chem., 1996, 61, 21222124.

8 G. Ding, S. Liu, L. Guo, Y. Zhou and Y. Che, J. Nat. Prod., 2008, 71, 615-618.

9 L. Liu, S. Liu, X. Chen, L. Guo and Y. Che, Bioorg. Med. Chem., 2009, 17, 606-613.

10 L. Liu, T. Bruhn, L. Guo, D. C. Goetz, R. Brun, A. Stich and G. Bringmann, Chem.-Eur. J., 2011, 17, 2604-2613.

11 H. Y. Tang, J. M. Gao and Q. Zhang, RSC Adv., 2015, 5, 7243372436.

12 I. G. Collado, J. R. Hanson and A. J. Macías-Sánchez, Nat. Prod. Rep., 1998, 15, 187-204.

13 J. P. Poyser, R. L. Edwards, J. R. Anderson, M. B. Hursthouse, N. P. C. Walker, G. M. Sheldrick and A. J. S. Whalley, J. Antibiot., 1986, 39, 167-169.

14 J. Gertsch, M. Leonti, S. Raduner, I. Racz, J. Z. Chen, X. Q. Xie and A. P. Zimmer, Proc. Natl. Acad. Sci. U. S. A., 2008, 105, 9099-9104.

15 H. Yu, W. X. Li, J. C. Wang, Q. Yang, H. J. Wang, C. C. Zhang and H. J. Zhu, Tetrahedron, 2015, 71, 3491-3494.

16 Y. Li, S. Niu, B. Sun, S. Liu, X. Liu and Y. Che, Org. Lett., 2010, 12, 3144-3147.

17 R. F. Magnan, E. Rodrigues-Fo, C. Daolio, A. G. Ferreira and A. Q. Z. de Souza, Z. Naturforsch., C: J. Biosci., 2003, 58, 319324.

18 Y. Li, C. W. Li, C. B. Cui, X. Z. Liu and Y. S. Che, Nat. Prod. Bioprospect., 2012, 2, 70-75.

19 S. T. Deyrup, D. C. Swenson, J. B. Gloer and D. T. Wicklow, J. Nat. Prod., 2006, 69, 608-611.

20 I. H. Hwang, J. B. Gloer and D. T. Wicklow, Planta Med., 2013, 79, PL11.

21 S. W. Yang, T. M. Chan, J. Terracciano, E. Boehm, R. Patel, G. Chen and M. Chu, J. Nat. Prod., 2009, 72, 484-487.

22 M. Wichlacz, W. A. Ayer, L. S. Trifonov, P. Chakravarty and D. Khasa, J. Nat. Prod., 1999, 62, 484-486.

23 J. R. Anderson, R. L. Edwards, J. P. Poyser and A. J. Whalley, J. Chem. Soc., Perkin Trans. 1, 1988, 4, 823-831.

24 J. R. Anderson, R. L. Edwards, A. A. Freer, R. P. Mabelis, J. P. Poyser, H. Spencer and A. J. Whalley, J. Chem. Soc., Chem. Commun., 1984, 14, 917-919.

25 T. M. Baker, D. J. Edmonds, D. Hamilton, C. J. O'Brien and D. J. Procter, Angew. Chem., Int. Ed., 2008, 47, 5631-5633.

26 J. Xiao, Q. Zhang, Y. Q. Gao, J. J. Tang, A. L. Zhang and J. M. Gao, J. Agric. Food Chem., 2014, 62, 3584-3590.

27 H. Li, J. Xiao, Y. Q. Gao, J. J. Tang, A. L. Zhang and J. M. Gao, J. Agric. Food Chem., 2014, 62, 3734-3741.

28 J. Xiao, Q. Zhang, Y. Q. Gao, X. W. Shi and J. M. Gao, Nat. Prod. Res., 2014, 28, 1388-1392. 
29 M. Pulici, F. Sugawara, H. Koshino, G. Okada, Y. Esumi, J. Uzawa and S. Yoshida, Phytochemistry, 1997, 46, 313-319.

30 Z. Wu, D. Liu, P. Proksch, P. Guo and W. Lin, Mar. Drugs, 2014, 12, 3904-3916.

31 J. R. Anderson, C. E. Briant, R. L. Edwards, R. P. Mabelis, J. P. Poyser, H. Spencer and A. J. Whalley, Chem. Commun., 1984, 7, 405-406.

32 M. Pulici, F. Sugawara, H. Koshino, J. Uzawa, S. Yoshida, E. Lobkovsky and J. Clardy, J. Nat. Prod., 1996, 59, 47-48.

33 J. G. Xing, H. Y. Deng and D. Q. Luo, J. Asian Nat. Prod. Res., 2011, 13, 1069-1073.

34 V. J. Paul, Y. Seo, K. W. Cho, J. R. Rho, J. Shin and P. R. Bergquist, J. Nat. Prod., 1997, 60, 1115-1120.

35 G. M. Sheldrick, SHELXTL-97 - A Program for Refining Crystal Structure, University of Goettingen, Goettingen, Germany, 1997.

36 Conflex 6.7, Conflex Corp., Tokyo Yokohama, Japan, 2010.

37 M. J. Frisch, G. W. Trucks, H. B. Schlegel, G. E. Scuseria, M. A. Robb, J. R. Cheeseman, G. Scalmani, V. Barone,
B. Mennucci, G. A. Petersson, H. Nakatsuji, M. Caricato, X. Li, H. P. Hratchian, A. F. Izmaylov, J. Bloino, G. Zheng, J. L. Sonnenberg, M. Hada, M. Ehara, K. Toyota, R. Fukuda, J. Hasegawa, M. Ishida, T. Nakajima, Y. Honda, O. Kitao, H. Nakai, T. Vreven, J. J. A. Montgomery, J. E. Peralta, F. Ogliaro, M. Bearpark, J. J. Heyd, E. Brothers, K. N. Kudin, V. N. Staroverov, R. Kobayashi, J. Normand, K. Raghavachari, A. Rendell, J. C. Burant, S. S. Iyengar, J. Tomasi, M. Cossi, N. Rega, N. J. Millam, M. Klene, J. E. Knox, J. B. Cross, V. Bakken, C. Adamo, J. Jaramillo, R. Gomperts, R. E. Stratmann, O. Yazyev, A. J. Austin, R. Cammi, C. Pomelli, J. W. Ochterski, R. L. Martin, K. Morokuma, V. G. Zakrzewski, G. A. Voth, P. Salvador, O. J. J. Dannenberg, S. Dapprich, A. D. Daniels, O. Farkas, J. B. Foresman, J. V. Ortiz, J. Cioslowski and D. J. Fox, Gaussian 09 revision D.01, Gaussian Inc., Wallingford, CT, 2013.

38 T. Bruhn, A. Schaumloeffel, Y. Hemberger and G. Bringmann, Chirality, 2013, 25, 243-249. 